\title{
Inter-comparison of Raingauges on Rainfall Amount and Intensity Measurements in a Tropical Environment
}

\author{
Ying-wa Chan, Choi-loi Yu and Kwong-hung Tam \\ Hong Kong Observatory, Hong Kong, China
}

\begin{abstract}
The HKO (Hong Kong Observatory) has been carrying out an inter-comparison of automatic raingauges since 2011 for identifying raingauges that can meet the $\pm 5 \%$ accuracy requirement of the WMO (World Meteorological Organization) in measuring rainfall amount. The inter-comparison was conducted at HKO's meteorological stations at King's Park and Hong Kong International Airport in Hong Kong. Two 0.1-mm resolution Pluvio-OTT weighing gauges were introduced in 2013. This type of raingauges has outperformed others in the WMO's field inter-comparison held between October 2007 and April 2009. The performances of 14 raingauges, comprising five different measurement methods, viz. drop-counting, weighing, tipping bucket with software correction, tipping bucket with extra pulse correction and tipping bucket without correction, were evaluated. The focus was to study their performances in rainfall intensity measurement, especially during heavy rain situations. Different high rainfall intensity episodes were selected for analysis. Among these episodes, the maximum 1-minute rainfall intensity as high as around $130 \mathrm{~mm} / \mathrm{hr}$ was recorded by the Pluvio-OTT raingauges. This paper serves to conclude the 3-year (2011-2013) inter-comparison exercise for rainfall amount measurements and to provide preliminary 1-year (2013) comparison results on rainfall intensity measurements.
\end{abstract}

Key words: Automatic raingauges, calibration, rainfall intensity, root mean square errors, mean absolute percentage differences.

\section{Introduction}

The HKO (Hong Kong Observatory) has been conducting field inter-comparison of automatic raingauges at its meteorological stations at KP (King's Park) and HKIA (Hong Kong International Airport) in Hong Kong since 2011. The objective of the comparison exercises is to identify which types of $0.1-\mathrm{mm}$ resolution raingauges can meet the $\pm 5 \%$ accuracy requirement of the WMO (World Meteorological Organization) [1] in measuring rainfall amount and are robust enough to be deployed in the field in tropics. Preliminary results of the inter-comparison conducted in 2011 and 2012 were summarized in Refs. [2, 3].

The inter-comparison continued in 2013 with the introduction of two $0.1-\mathrm{mm}$ resolution

Corresponding author: Ying-wa Chan, Mr., research fields: weather forecasting, meteorological instrumentation and inter-comparison of instruments. E-mail: ywchan @ hko.gov.hk.
Pluvio-OTT $^{1}$ (hereafter OTT) weighing gauges at the $\mathrm{KP}$ test site to serve as the reference raingauges for benchmarking the performances of other raingauges in rainfall intensity measurements.

In a tropical environment like Hong Kong where rainfall intensity can exceed $300 \mathrm{~mm} / \mathrm{hr}$ in the rainy season, the inter-comparison at KP and HKIA provides a good opportunity to evaluate quantitatively the performances of various raingauges in both rainfall amount and intensity measurements. The latter, in particular, has become more important as improvements of rainfall intensity measurements could provide valuable information for consideration of rainstorm warnings to help mitigating the impact of

\footnotetext{
1 During the WMO laboratory inter-comparison of rainfall intensity gauges held between September 2004 and September 2005, the Pluvio-OTT weighing gauge has shown excellent accuracy in constant flow conditions with relative error less than $\pm 2 \%$ in the calibration range of $2-1,200 \mathrm{~mm} / \mathrm{hr}$ [6]. It also outperformed other raingauges during the WMO's field inter-comparison of rainfall intensity gauges held between October 2007 and April 2009 in Vigna di Valle, Italy [7].
} 
severe weather events [4-5].

\section{Procedures and Methods}

\subsection{Selection of Instruments and Inter-comparison Sites}

A total of 14 raingauges comprising five different measurement methods, viz. drop-counting, weighing, tipping bucket without correction, tipping bucket with software correction and tipping bucket with extra pulse correction, have been chosen for the comparison. Details of the raingauge types installed at KP and HKIA for the inter-comparison are shown in Table 1 and Table 2 respectively, and the corresponding photos of the equipment set up at these two test sites are shown in Fig. 1 and Fig. 2 respectively. HKO's manned meteorological stations at KP and HKIA with good exposure were chosen as the field inter-comparison sites. The design and rationale of the equipment layout at KP and HKIA are described in Ref. [2].

\subsection{Instrument Calibration}

All raingauges have been calibrated in-house before deployment to the field. Detailed procedures for carrying out in-house calibration of the raingauges, the calibration results of each type of raingauge and the method used to conduct on-site calibration checks of the raingauges installed at the two test beds have been summarized in Ref. [2].

The two OTT weighing gauges were also calibrated in-house before installing at the KP test site in June 2013 and they both showed good accuracy (Fig. 3). For rainfall amount, the measurement uncertainties can meet the WMO's $\pm 5 \%$ accuracy requirement in the whole calibration range from around $30 \mathrm{~mm} / \mathrm{hr}$ to $400 \mathrm{~mm} / \mathrm{hr}$. For rainfall intensity, it can also meet the WMO's $\pm 2 \%$ accuracy requirement for flow rate exceeding $10 \mathrm{~mm} / \mathrm{hr}$. It is thus considered suitable to deploy the two OTT weighing gauges as reference rainfall intensity gauges for benchmarking the performances of other raingauges at the KP test site.

\section{Results}

At KP, a total of 142 rain episodes defined as 24-hr rainfall $\geq 10 \mathrm{~mm}$ recorded by one of the two manual raingauges (Manual (A) raingauge as shown in Fig. 1 at KP) were recorded from April 1, 2011 to October $30,2013^{2}$.

Similarly at HKIA, 127 rain episodes (defined as 24-hr rainfall $\geq 10 \mathrm{~mm}$ recorded by the manual raingauge at HKIA) occurred from 19 March 2011 to 31 December 2013.

\subsection{4-hr Total Rainfall}

The performance of raingauges at $\mathrm{KP}$ is summarized in Table 3 and Fig. 4, while the results at HKIA are shown in Table 4 and Fig. 5. The RMSE (root mean square errors), MAPD (mean absolute percentage differences) and standard deviations of percentage errors were all calculated with reference to the manual raingauges at the two sites.

At KP, it was observed that:

(1) Apart from ETG, all raingauges had MAPD less than 5\% and met the WMO accuracy requirement, except for the Logotronic raingauges (Logotronic (A) and Logotronic (B)) which had a MAPD exceeding $5 \%$ for 24 -hr rainfall $\geq 50 \mathrm{~mm}$. The MAPD for ETG were greater than $5 \%$ for all rain episodes;

(2) The MAPD of the Casella 0.5-mm resolution raingauges were $2.8 \%$, indicating an accuracy that could meet WMO's requirement despite having a coarser resolution;

(3) The MAPD of the two Logotronic raingauges (4.5\% and 4.8\%) were larger than the two SL3-1 raingauges $(3.1 \%$ and $2.6 \%)$. The corresponding RMSE for the two Logotronic raingauges $(2.6 \mathrm{~mm}$ and $3.6 \mathrm{~mm}$ ) were also larger than the two SL3-1 raingauges $(1.8 \mathrm{~mm}$ and $1.7 \mathrm{~mm})$. This seemed to suggest slightly better performance of SL3-1;

(4) The MAPD of the ETG raingauge was 5.8\%, the largest among all raingauges at the site. Differences

\footnotetext{
2 The raingauges were removed from the KP test site for re-calibration in the laboratory in November 2013.
} 
Table 1 Types of raingauges installed at the King's Park Meteorological Station for the field inter-comparison.

\begin{tabular}{llll}
\hline Raingauge & Measuring principle/data correction algorithm & Resolution (mm) & $\begin{array}{l}\text { Maximum rainfall intensity } \\
\text { declared (mm/hr) }\end{array}$ \\
\hline Logotronic MRF-C & Tipping bucket (with extra pulse correction) & 0.1 & 200 \\
Shanghai SL3-1 & Two layers of tipping buckets & 0.1 & 240 \\
ETG-R102 (ETG) & Tipping bucket (with software correction) & $0.2^{\mathrm{a}}$ & 300 \\
Ordinary 203-mm raingauge & Manual (serves as benchmark) & 0.1 & - \\
Pluvio-OTT & Weighing & 0.1 & 1,800 \\
Casella 100573E & Tipping bucket (no correction) & 0.5 & 300 \\
\hline
\end{tabular}

${ }^{\mathrm{a}}$ Recommended in Ref. [6].

Table 2 Types of raingauges installed at the Hong Kong International Airport Meteorological Station for the field inter-comparison.

\begin{tabular}{llll}
\hline Raingauge & Measuring principle/data correction algorithm & Resolution (mm) & $\begin{array}{l}\text { Maximum rainfall intensity } \\
\text { declared (mm/hr) }\end{array}$ \\
\hline Ogawa & Drop-counting & 0.1 & 200 \\
Logotronic MRF-C & Tipping bucket (with extra pulse correction) & 0.1 & 200 \\
Shanghai SL3-1 & Two layers of tipping bucket & 0.1 & 240 \\
Meteoservis & Weighing & 0.1 & 400 \\
Ordinary 160-mm raingauge & Manual (serves as benchmark) & 0.1 & - \\
\hline
\end{tabular}

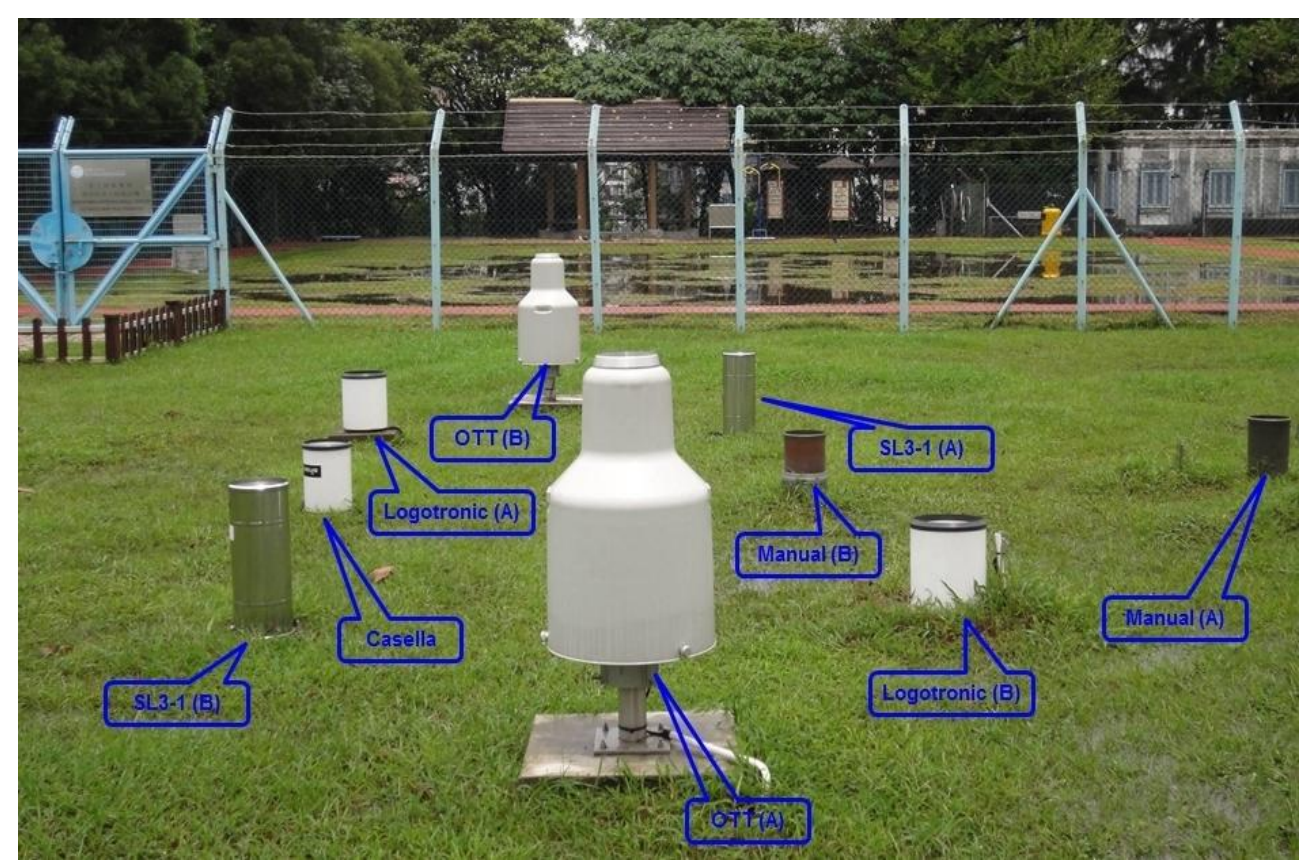

Fig. 1 Locations of raingauges at the King's Park Meteorological Station test bed (The location of OTT (B) raingauge was originally occupied by the ETG raingauge which malfunctioned in November 2011 and was removed from the test site).

for all three rainfall sub-categories also exceeded $5 \%$. The performance of ETG was less satisfactory than the other raingauges. More importantly, the electronic device of the raingauge for carrying out software correction malfunctioned in November 2011 and it could not be resumed to normal operation. The ETG raingauge was withdrawn from the $\mathrm{KP}$ test site afterwards;

(5) Discounting the Casella raingauge, the MAPD differed by less than $1 \%$ for the same model of raingauges. Since the 24-hr rainfall recorded by the two manual gauges only differed by a maximum of 


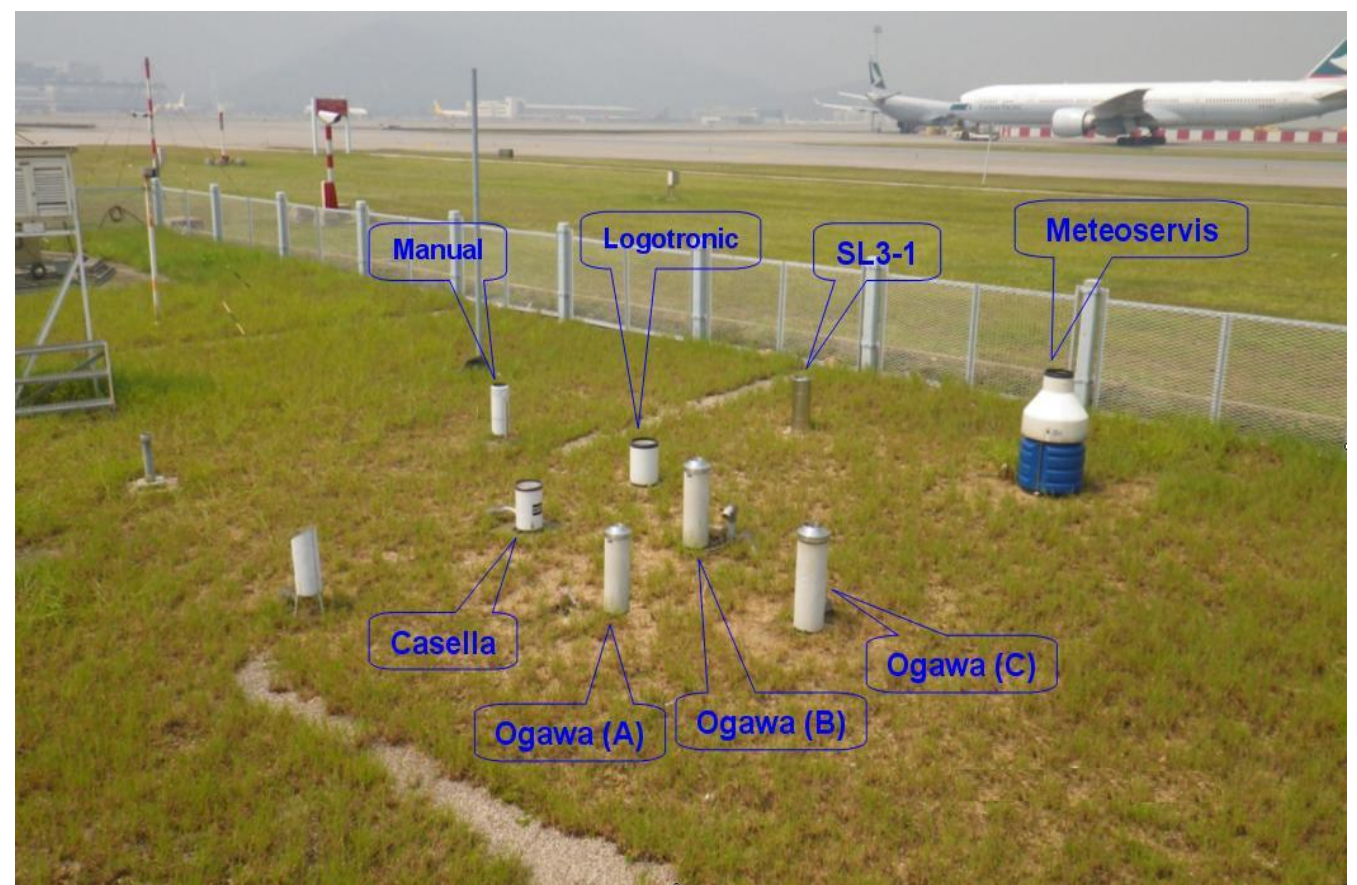

Fig. 2 Locations of raingauges at the Hong Kong International Airport Meteorological Station test bed (The manual raingauge was relocated closer to the other raingauges in 2012 and the new location of the manual raingauge is shown).

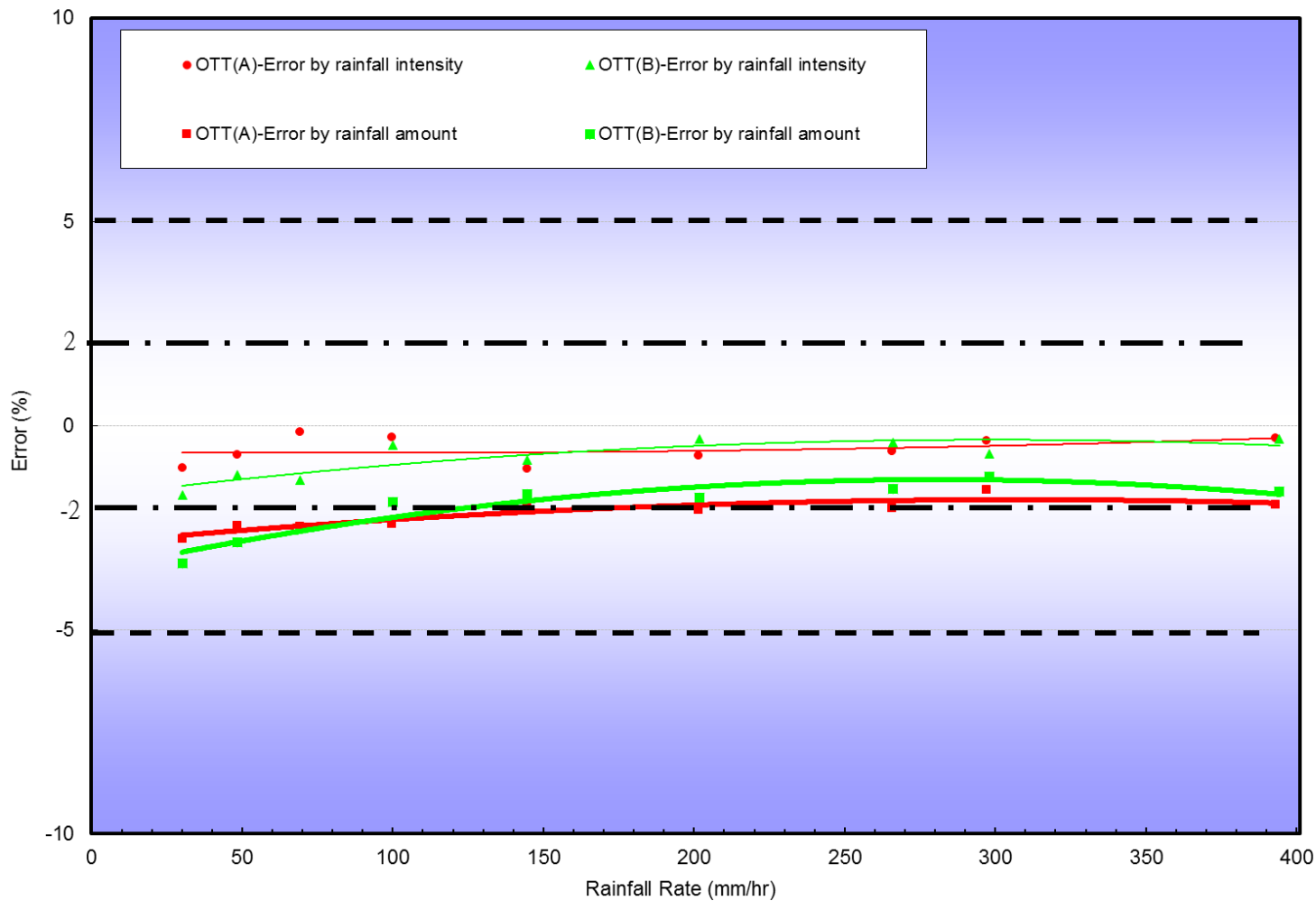

Fig. 3 Error curves (compared with WMO's $\pm 2 \%$ and $\pm 5 \%$ uncertainty limits for rainfall intensity and rainfall amount accuracy requirements respectively) obtained in the laboratory under different simulated rainfall rates for the two Pluvio-OTT weighing gauges before deployment to the King's Park site (second order polynomial functions are used for curve fitting). 
Table 3 Summary of rainfall comparison results at the King's Park Meteorological Station (April 1, 2011-October 30, 2013).

\begin{tabular}{|c|c|c|c|c|c|c|c|c|c|}
\hline \multirow[b]{2}{*}{ Rainfall event } & \multicolumn{9}{|c|}{ Type of raingauges } \\
\hline & $\begin{array}{l}\text { Casella } \\
(0.5 \mathrm{~mm})\end{array}$ & $\begin{array}{l}\text { SL3-1 } \\
(\mathrm{A}) \\
(0.1 \mathrm{~mm})\end{array}$ & $\begin{array}{l}\text { SL3-1 (B) } \\
(0.1 \mathrm{~mm})\end{array}$ & $\begin{array}{l}\text { Logotronic } \\
\text { (A) } \\
(0.1 \mathrm{~mm})\end{array}$ & $\begin{array}{l}\text { Logotronic } \\
\text { (B) } \\
(0.1 \mathrm{~mm})\end{array}$ & $\begin{array}{l}\text { OTT (A) } \\
(0.1 \mathrm{~mm})\end{array}$ & $\begin{array}{l}\text { OTT (B) } \\
(0.1 \mathrm{~mm})\end{array}$ & $\begin{array}{l}\text { ETG } \\
(0.2 \mathrm{~mm})\end{array}$ & $\begin{array}{l}\text { Manual } \\
\text { (A) }\end{array}$ \\
\hline $\begin{array}{l}\text { No. of rain episodes } \\
\text { All }(\geq 10 \mathrm{~mm})\end{array}$ & $140^{b}$ & $134^{\mathrm{b}}$ & $140^{\mathrm{b}}$ & $136^{\mathrm{b}}$ & $106^{\mathrm{b}}$ & $38^{\mathrm{c}}$ & $\mathbf{3 8}^{\mathrm{c}}$ & $\mathbf{3 3}^{\mathrm{d}}$ & 142 \\
\hline $\operatorname{RMSE}^{\mathrm{a}}(\mathrm{mm})$ & 1.9 & 1.8 & 1.7 & 2.6 & 3.6 & 2.6 & 2.5 & 2.6 & \\
\hline MAPD $^{\mathrm{a}}$ & $2.8 \%$ & $3.1 \%$ & $2.6 \%$ & $4.5 \%$ & $4.8 \%$ & $3.4 \%$ & $3.3 \%$ & $5.8 \%$ & \\
\hline $\begin{array}{l}\text { No. of rain episodes } \\
\geq 10 \mathrm{~mm} \text { and }<25 \mathrm{~mm}\end{array}$ & 65 & 62 & 65 & 61 & 54 & 15 & 15 & 16 & 67 \\
\hline $\operatorname{RMSE}^{\mathrm{a}}(\mathrm{mm})$ & 0.9 & 0.9 & 0.8 & 1.3 & 1.2 & 1.4 & 1.4 & 1.1 & \\
\hline MAPD $^{\mathrm{a}}$ & $3.2 \%$ & $3.6 \%$ & $2.7 \%$ & $4.8 \%$ & $4.8 \%$ & $4.2 \%$ & $4.5 \%$ & $5.4 \%$ & \\
\hline $\begin{array}{l}\text { No. of rain episodes } \\
\geq 25 \mathrm{~mm} \text { and }<50 \mathrm{~mm}\end{array}$ & 40 & 37 & 40 & 40 & 30 & 11 & 11 & 6 & 40 \\
\hline $\operatorname{RMSE}^{\mathrm{a}}(\mathrm{mm})$ & 1.4 & 1.5 & 1.2 & 1.6 & 2.0 & 1.6 & 1.4 & 2.5 & \\
\hline MAPD $^{\mathrm{a}}$ & $2.3 \%$ & $2.9 \%$ & $2.3 \%$ & $3.6 \%$ & $3.8 \%$ & $2.2 \%$ & $1.7 \%$ & $7.9 \%$ & \\
\hline $\begin{array}{l}\text { No. of rain episodes } \\
\geq 50 \mathrm{~mm}\end{array}$ & 35 & 35 & 35 & 35 & 22 & 12 & 12 & 11 & 35 \\
\hline $\operatorname{RMSE}^{\mathrm{a}}(\mathrm{mm})$ & 3.4 & 2.8 & 2.9 & 4.6 & 7.4 & 4.0 & 3.9 & 3.9 & \\
\hline MAPD $^{\mathrm{a}}$ & $2.7 \%$ & $2.6 \%$ & $2.7 \%$ & $5.2 \%$ & $5.9 \%$ & $3.5 \%$ & $3.4 \%$ & $5.2 \%$ & \\
\hline
\end{tabular}

${ }^{a}$ Reference was made to Manual (A) rain gauge at the KP test site in compiling RMSE and MAPD;

${ }^{\mathrm{b}}$ Fewer no. of rain episodes was due to maintenance of the raingauges;

${ }^{c}$ Fewer no. of rain episodes as the two OTT raingauges only started operation on June 4, 2013;

${ }^{\mathrm{d}}$ The ETG raingauge malfunctioned in November 2011 and was withdrawn from the test site.

Table 4 Summary of rainfall comparison results at the Hong Kong International Airport Meteorological Station (March 19, 2011-December 31, 2013).

\begin{tabular}{|c|c|c|c|c|c|c|c|}
\hline \multirow[b]{2}{*}{ Rainfall event } & \multicolumn{7}{|c|}{ Type of raingauge } \\
\hline & $\begin{array}{l}\text { Ogawa A } \\
(0.1 \mathrm{~mm})\end{array}$ & $\begin{array}{l}\text { Ogawa B } \\
(0.1 \mathrm{~mm})\end{array}$ & $\begin{array}{l}\text { Ogawa C } \\
(0.1 \mathrm{~mm})\end{array}$ & $\begin{array}{l}\text { Logotronic } \\
(0.1 \mathrm{~mm})\end{array}$ & $\begin{array}{l}\text { Meteoservis } \\
(0.1 \mathrm{~mm})\end{array}$ & $\begin{array}{l}\text { SL3-1 } \\
(0.1 \mathrm{~mm})\end{array}$ & Manual \\
\hline $\begin{array}{l}\text { No. of rain episodes } \\
\text { All }(\geq 10 \mathrm{~mm})\end{array}$ & $118^{\mathrm{b}}$ & $57^{\mathrm{c}}$ & $121^{\mathrm{b}}$ & $126^{\mathrm{b}}$ & $67^{\mathrm{c}}$ & $123^{\mathrm{b}}$ & 127 \\
\hline $\operatorname{RMSE}^{\mathrm{a}}(\mathrm{mm})$ & 4.1 & 2.4 & 2.4 & 2.5 & 3.7 & 3.4 & \\
\hline MAPD $^{\mathrm{a}}$ & $4.9 \%$ & $4.6 \%$ & $4.9 \%$ & $7.1 \%$ & $3.5 \%$ & $5.9 \%$ & \\
\hline $\begin{array}{l}\text { No. of rain episodes } \\
\geq 10 \mathrm{~mm} \text { and }<25 \mathrm{~mm}\end{array}$ & 66 & 28 & 67 & 71 & 36 & 70 & 72 \\
\hline $\operatorname{RMSE}^{\mathrm{a}}(\mathrm{mm})$ & 1.0 & 1.0 & 1.1 & 1.5 & 0.7 & 1.2 & \\
\hline MAPD $^{\mathrm{a}}$ & $4.8 \%$ & $5.3 \%$ & $5.4 \%$ & $8.6 \%$ & $3.6 \%$ & $6.8 \%$ & \\
\hline $\begin{array}{l}\text { No. of rain episodes } \\
\geq 25 \mathrm{~mm} \text { and }<50 \mathrm{~mm}\end{array}$ & 27 & 14 & 28 & 29 & 16 & 27 & 29 \\
\hline $\operatorname{RMSE}^{\mathrm{a}}(\mathrm{mm})$ & 2.4 & 2.0 & 1.9 & 2.2 & 0.8 & 2.4 & \\
\hline MAPD $^{\mathrm{a}}$ & $5.0 \%$ & $4.4 \%$ & $4.3 \%$ & $6.0 \%$ & $2.4 \%$ & $5.2 \%$ & \\
\hline $\begin{array}{l}\text { No. of rain episodes } \\
\geq 50 \mathrm{~mm}\end{array}$ & 25 & 15 & 26 & 26 & 15 & 26 & 26 \\
\hline $\operatorname{RMSE}^{\mathrm{a}}(\mathrm{mm})$ & 8.4 & 4.1 & 4.3 & 4.4 & 7.7 & 6.6 & \\
\hline MAPD $^{\mathrm{a}}$ & $5.2 \%$ & $3.7 \%$ & $4.3 \%$ & $4.2 \%$ & $4.4 \%$ & $4.3 \%$ & \\
\hline
\end{tabular}

${ }^{a}$ Reference was made to the manual rain gauge at the HKIA test site in compiling RMSE and MAPD.

${ }^{\mathrm{b}}$ Fewer no. of rain episodes was due to maintenance of the raingauges.

${ }^{c}$ The Ogawa B and Meteoservis raingauges malfunctioned in August 2012 and December 2012 respectively and they were withdrawn from the comparison site. 
Measurements in a Tropical Environment
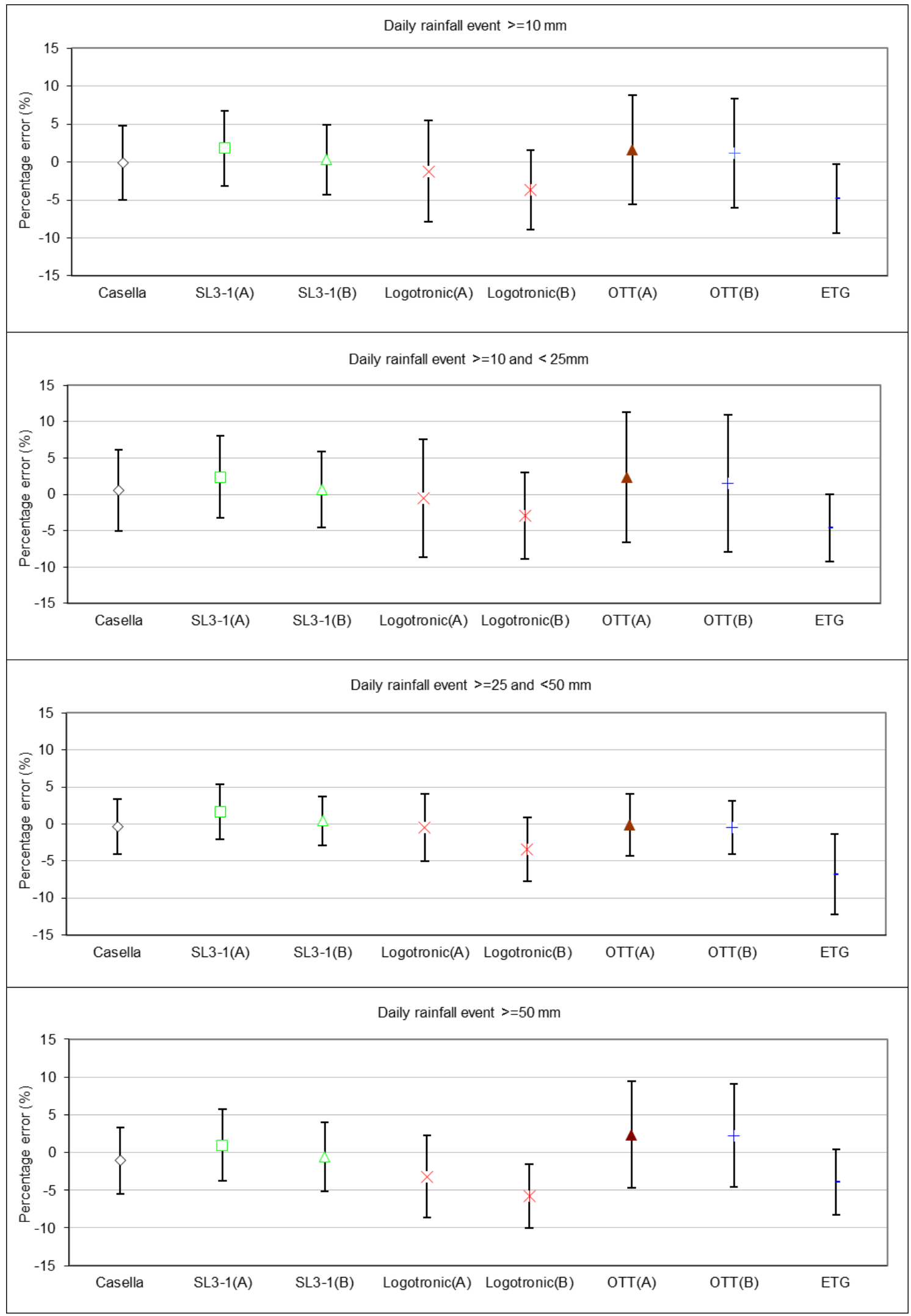

Fig. 4 Mean percentage errors of various raingauges (compared to manual gauge (A)) at the KP site. Vertical bar denotes \pm 1 standard deviation. 


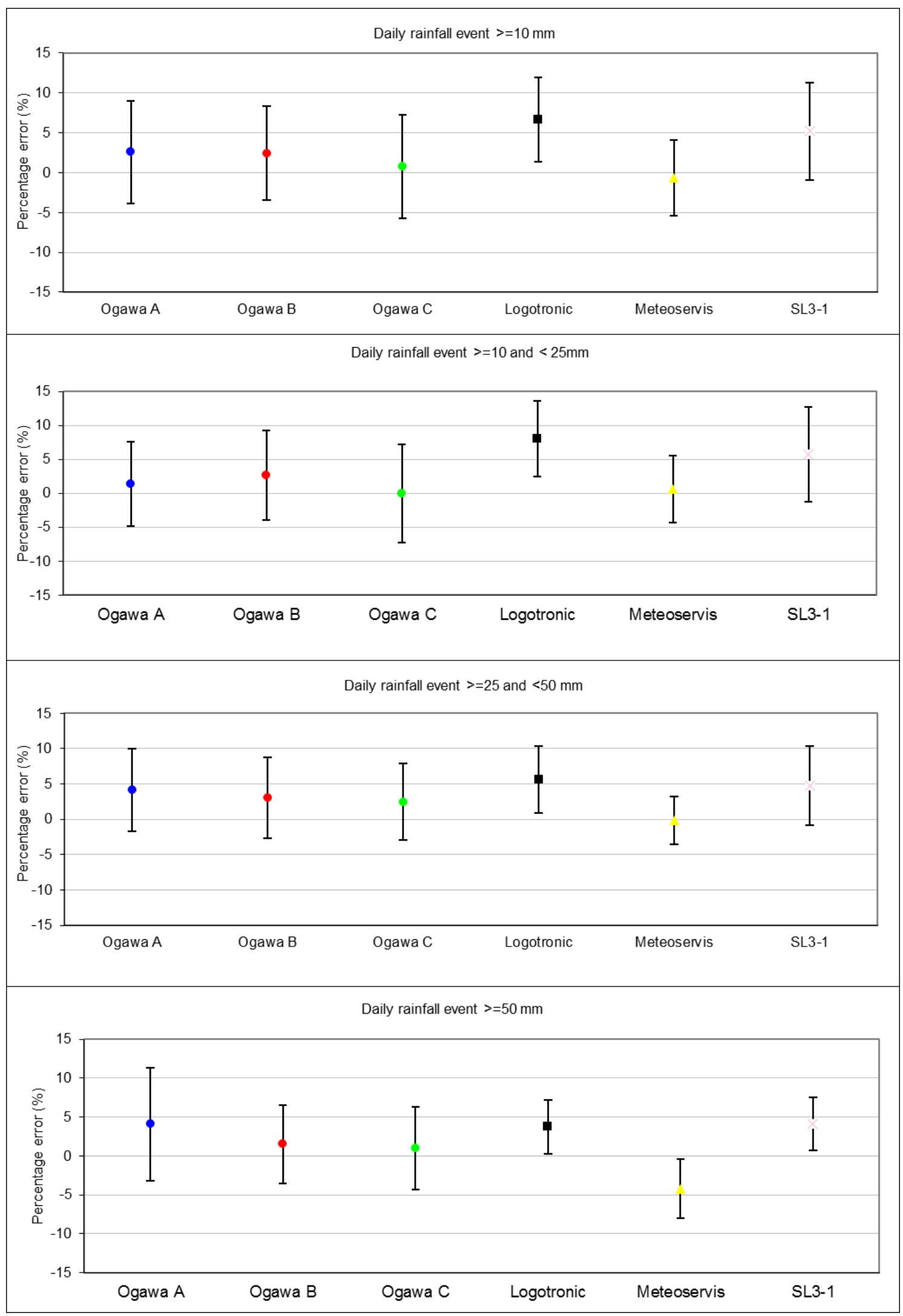

Fig. 5 Mean percentage errors of various raingauges (compared to the manual gauge) at the HKIA site. Vertical bar denotes \pm 1 standard deviation. 
$2.0 \mathrm{~mm}$ during the whole test period, the spatial variability of rainfall recorded by the raingauges at KP was thus very small during the period.

At HKIA, some notable points were:

(1) The MAPD of Ogawa A, Ogawa B, Ogawa C and Logotronic raingauges were $4.9 \%, 4.6 \%, 4.9 \%$ and $7.1 \%$ respectively. All could meet the WMO's \pm $5 \%$ accuracy requirement except for the Logotronic raingauge. The Ogawa B raingauge failed to operate in August 2012 due to problems with its electronics and it was then taken out of the comparison site;

(2) SL3-1 performed not as good as the two sets of SL3-1 at the KP test site and the MAPD was 5.9\%. However, after relocating the manual raingauge closer to other raingauges in 2012 and fine-tuning the tipping mechanism of the SL3-1 raingauge, the recent results from 23 November 2012 to 31 December 2013 showed improvements and the MAPD dropped to $4.9 \%$ for all rainfall events $\geq 10 \mathrm{~mm}$, meeting the WMO's $\pm 5 \%$ accuracy requirement;

(3) The MAPD of Meteoservis raingauge were less than $5 \%$ in all rainfall categories, meeting the WMO's $\pm 5 \%$ accuracy requirement. However, it malfunctioned in December 2012 and could not be resumed operation. The raingauge was subsequently removed from the HKIA test site.

\subsection{Rainfall Intensity}

A comparison of the 1-minute mean and 5-minute mean rainfall intensity recorded by the raingauges at KP between June 4, 2013 and October 30, 2013 was conducted using the two OTT as the reference raingauges. During this nearly 5-month period, the two OTT gauges recorded the highest 1-minute mean rainfall intensity of around $130 \mathrm{~mm} / \mathrm{hr}$ on June 11 , 2013.

Different rainfall intensity episodes (defined based on five consecutive 1-minute mean rainfall intensity from the averages of the two OTT reference raingauges exceeding $10 \mathrm{~mm} / \mathrm{hr}, 30 \mathrm{~mm} / \mathrm{hr}, 50 \mathrm{~mm} / \mathrm{hr}$, $70 \mathrm{~mm} / \mathrm{hr}$ and $100 \mathrm{~mm} / \mathrm{hr}$ respectively) have been selected for comparison. The results are shown in Table 5 and Table 6 respectively. Except for the two OTT raingauges which have direct rainfall intensity output, rainfall intensity for all other gauges were derived from multiplying the 1-minute total rainfall by 60 . Hence, for tip resolution of $0.1 \mathrm{~mm}$ and $0.5 \mathrm{~mm}$, the resolution of rainfall intensity will be $6 \mathrm{~mm} / \mathrm{hr}$ and $30 \mathrm{~mm} / \mathrm{hr}$ respectively over a period of 1 minute [6].

From the results in Tables 5 and 6 , it can be observed that:

(1) Due to the high natural variability of rainfall intensity, the RMSE and MAPD associated with 1-minute mean rainfall intensity were a lot higher than those of the 5-minute mean rainfall intensity. This was consistent with the findings in Ref. [7];

(2) For 5-minute mean rainfall intensity, the RMSE and MAPD of the two SL3-1 raingauges were $<5$ $\mathrm{mm} / \mathrm{hr}$ for intensity $\leq 100 \mathrm{~mm} / \mathrm{hr}$, and $<5 \%$ for intensity > $100 \mathrm{~mm} / \mathrm{hr}$ (except for SL3-1 (B) for intensity > $30 \mathrm{~mm} / \mathrm{hr}$ with RMSE of $5.1 \mathrm{~mm} / \mathrm{hr}$, slightly exceeding the WMO's requirement of 5 $\mathrm{mm} / \mathrm{hr}$ ). The results showed that the performance of SL3-1 was the best among other raingauges in the comparison. This suggested that 5-minute mean rainfall intensity measured by SL3-1 would possibly be able to meet WMO's accuracy requirement in rainfall intensity measurements.

\subsection{Rainfall Intensity Derived from Successive Rainfall Tips}

In 2014, a software program for acquiring rainfall data from the raingauges at KP was implemented to enable recording of the occurrence time of individual rainfall tips. Hence, the time difference of successive rainfall tips can be used to derive the short-term or near instantaneous rainfall intensity. The 1-minute mean rainfall intensity was then obtained by taking the average of rainfall intensity derived from successive rainfall tips over a 1-minute interval.

There are thus two different methods to calculate the 1-minute mean rainfall intensity. One is based on 
Table 5 Summary of 1-minute mean rainfall intensity comparison results at KP (June 4, 2013-October 30, 2013).

\begin{tabular}{|c|c|c|c|c|c|c|}
\hline \multirow[b]{2}{*}{ Rainfall event } & \multicolumn{6}{|c|}{ Type of raingauge } \\
\hline & Casella & SL3-1 (A) & SL3-1 (B) & Logotronic (A) & Logotronic (B) & $\begin{array}{l}\text { Mean of OTT (A) } \\
\text { and OTT (B) }\end{array}$ \\
\hline No. of rain episodes ${ }^{\mathrm{a}}>10 \mathrm{~mm} / \mathrm{hr}$ & 166 & 166 & 166 & 166 & $105^{\mathrm{c}}$ & 166 \\
\hline $\operatorname{RMSE}^{\mathrm{b}}(\mathrm{mm} / \mathrm{hr})$ & 17.7 & 12.4 & 12.4 & 13.0 & 12.0 & \\
\hline MAPD $^{\mathrm{b}}$ & $59.3 \%$ & $29.5 \%$ & $28.1 \%$ & $29.6 \%$ & $28.4 \%$ & \\
\hline No. of rain episodes ${ }^{\mathrm{a}}>30 \mathrm{~mm} / \mathrm{hr}$ & 58 & 58 & 58 & 58 & 33 & 58 \\
\hline $\operatorname{RMSE}^{\mathrm{b}}(\mathrm{mm} / \mathrm{hr})$ & 19.5 & 14.9 & 15.1 & 15.5 & 14.1 & \\
\hline MAPD $^{\mathrm{b}}$ & $27.2 \%$ & $18.7 \%$ & $18.7 \%$ & $19.5 \%$ & $17.7 \%$ & \\
\hline No. of rain episodes ${ }^{\mathrm{a}}>50 \mathrm{~mm} / \mathrm{hr}$ & 26 & 26 & 26 & 26 & 15 & 26 \\
\hline $\operatorname{RMSE}^{\mathrm{b}}(\mathrm{mm} / \mathrm{hr})$ & 20.6 & 15.8 & 16.5 & 17.0 & 15.3 & \\
\hline MAPD $^{\mathrm{b}}$ & $19.9 \%$ & $14.2 \%$ & $15.0 \%$ & $15.8 \%$ & $14.2 \%$ & \\
\hline No. of rain episodes ${ }^{\mathrm{a}}>70 \mathrm{~mm} / \mathrm{hr}$ & 7 & 7 & 7 & 7 & 3 & 7 \\
\hline $\operatorname{RMSE}^{\mathrm{b}}(\mathrm{mm} / \mathrm{hr})$ & 20.5 & 15.8 & 16.7 & 16.7 & 12.7 & \\
\hline MAPD $^{\mathrm{b}}$ & $17.6 \%$ & $11.9 \%$ & $12.9 \%$ & $13.3 \%$ & $9.2 \%$ & \\
\hline No. of rain episodes ${ }^{\mathrm{a}}>100 \mathrm{~mm} / \mathrm{hr}$ & 2 & 2 & 2 & 2 & 2 & 2 \\
\hline $\operatorname{RMSE}^{\mathrm{b}}(\mathrm{mm} / \mathrm{hr})$ & 12.7 & 8.9 & 11.2 & 11.2 & 13.3 & \\
\hline MAPD $^{b}$ & $8.5 \%$ & $5.3 \%$ & $6.6 \%$ & $7.0 \%$ & $7.8 \%$ & \\
\hline
\end{tabular}

${ }^{\mathrm{a}}$ Rain episodes are defined as 5-consective 1-minute mean rainfall intensity from the averages of OTT (A) and OTT (B) reference raingauges exceeding $10 \mathrm{~mm} / \mathrm{hr}, 30 \mathrm{~mm} / \mathrm{hr}, 50 \mathrm{~mm} / \mathrm{hr}, 70 \mathrm{~mm} / \mathrm{hr}$ and $100 \mathrm{~mm} / \mathrm{hr}$ respectively;

${ }^{\mathrm{b}}$ Reference was made to the 1-minute mean rainfall intensity recorded by the two OTT raingauges (WMO's achievable measurement uncertainty for rainfall intensity measurement in field environment is $5 \mathrm{~mm} / \mathrm{hr}$ or $5 \%$ above $100 \mathrm{~mm} / \mathrm{hr}$ );

${ }^{c}$ Fewer no. of rain episodes as the Logotronic (B) raingauge malfunctioned since August 23, 2013.

Table 6 Summary of 5-minute mean rainfall intensity comparison results at KP (June 4, 2013-October 30, 2013).

\begin{tabular}{|c|c|c|c|c|c|c|}
\hline \multirow[b]{2}{*}{ Rainfall event } & \multicolumn{6}{|c|}{ Type of raingauge } \\
\hline & Casella & SL3-1 (A) & SL3-1 (B) & Logotronic (A) & Logotronic (B) & $\begin{array}{l}\text { Mean of OTT (A) } \\
\text { and OTT (B) }\end{array}$ \\
\hline No. of rain episodes ${ }^{\mathrm{a}}>10 \mathrm{~mm} / \mathrm{hr}$ & 166 & 166 & 166 & 166 & $105^{\mathrm{c}}$ & 166 \\
\hline $\operatorname{RMSE}^{\mathrm{b}}(\mathrm{mm} / \mathrm{hr})$ & 5.3 & 4.4 & 4.5 & 4.9 & 5.6 & \\
\hline MAPD $^{b}$ & $11.3 \%$ & $8.2 \%$ & $8.2 \%$ & $9.3 \%$ & $10.7 \%$ & \\
\hline No. of rain episodes ${ }^{\mathrm{a}}>30 \mathrm{~mm} / \mathrm{hr}$ & 58 & 58 & 58 & 58 & 33 & 58 \\
\hline $\operatorname{RMSE}^{\mathrm{b}}(\mathrm{mm} / \mathrm{hr})$ & 5.9 & 4.9 & 5.1 & 5.5 & 7.3 & \\
\hline MAPD $^{b}$ & $7.2 \%$ & $5.7 \%$ & $5.9 \%$ & $7.0 \%$ & $9.1 \%$ & \\
\hline No. of rain episodes ${ }^{\mathrm{a}}>50 \mathrm{~mm} / \mathrm{hr}$ & 26 & 26 & 26 & 26 & 15 & 26 \\
\hline $\operatorname{RMSE}^{\mathrm{b}}(\mathrm{mm} / \mathrm{hr})$ & 6.2 & 4.5 & 4.5 & 5.9 & 7.6 & \\
\hline MAPD $^{b}$ & $5.9 \%$ & $4.2 \%$ & $4.2 \%$ & $6.0 \%$ & $7.8 \%$ & \\
\hline No. of rain episodes ${ }^{\mathrm{a}}>70 \mathrm{~mm} / \mathrm{hr}$ & 7 & 7 & 7 & 7 & 3 & 7 \\
\hline $\operatorname{RMSE}^{\mathrm{b}}(\mathrm{mm} / \mathrm{hr})$ & 6.6 & 4.8 & 4.3 & 6.4 & 7.3 & \\
\hline MAPD $^{\mathrm{b}}$ & $5.1 \%$ & $3.9 \%$ & $3.4 \%$ & $5.3 \%$ & $5.4 \%$ & \\
\hline No. of rain episodes ${ }^{\mathrm{a}}>100 \mathrm{~mm} / \mathrm{hr}$ & 2 & 2 & 2 & 2 & 2 & 2 \\
\hline $\operatorname{RMSE}^{\mathrm{b}}(\mathrm{mm} / \mathrm{hr})$ & 3.2 & 2.7 & 2.9 & 6.5 & 5.9 & \\
\hline MAPD $^{b}$ & $2.2 \%$ & $1.9 \%$ & $2.2 \%$ & $5.2 \%$ & $4.5 \%$ & \\
\hline
\end{tabular}

${ }^{\mathrm{a}}$ Rain episodes are defined as 5-consective 1-minute mean rainfall intensity from the averages of OTT (A) and OTT (B) reference raingauges exceeding $10 \mathrm{~mm} / \mathrm{hr}, 30 \mathrm{~mm} / \mathrm{hr}, 50 \mathrm{~mm} / \mathrm{hr}, 70 \mathrm{~mm} / \mathrm{hr}$ and $100 \mathrm{~mm} / \mathrm{hr}$ respectively;

${ }^{\mathrm{b}}$ Reference was made to the 5-minute mean rainfall intensity recorded by the two OTT raingauges;

${ }^{c}$ Fewer no. of rain episodes as the Logotronic (B) raingauge malfunctioned since August 23, 2013. 
Table 7 Evaluation of SL3-1 raingauge on rainfall intensity measurements using different methods to calculate the 1-minute mean rainfall intensity.

\begin{tabular}{|c|c|c|c|c|c|c|c|c|}
\hline \multirow[t]{2}{*}{ Method to calculate rainfall intensity } & \multicolumn{8}{|c|}{$\begin{array}{l}\text { Reference 1-minute mean rainfall intensity } \\
\text { calculated based on the change of water weight }(\mathrm{mm} / \mathrm{hr})\end{array}$} \\
\hline & 6.5 & 13.3 & 26.2 & 65.3 & 132.0 & 197.7 & 267.2 & 411.3 \\
\hline $\begin{array}{l}\text { 1-minute mean rainfall intensity calculated based on } \\
1 \text {-minute total rainfall x } 60(\mathrm{~mm} / \mathrm{hr})\end{array}$ & 6.3 & 13.2 & 25.3 & 63.5 & 131.5 & 199.2 & 271.5 & 384.0 \\
\hline Mean percentage difference ${ }^{a}$ & $-3.1 \%$ & $-0.8 \%$ & $-3.4 \%$ & $-2.8 \%$ & $-0.4 \%$ & $0.8 \%$ & $1.6 \%$ & $-6.6 \%$ \\
\hline $\begin{array}{l}\text { 1-minute mean rainfall intensity calculated based on the } \\
\text { average of rainfall intensity derived from successive } \\
\text { rainfall tips over a 1-minute interval }(\mathrm{mm} / \mathrm{hr})\end{array}$ & 6.5 & 14.5 & 26.6 & 73.1 & 142.3 & 206.2 & 274.3 & 384.4 \\
\hline Mean percentage difference ${ }^{\mathrm{a}}$ & $0.0 \%$ & $9.0 \%$ & $1.5 \%$ & $11.9 \%$ & $7.8 \%$ & $4.3 \%$ & $2.7 \%$ & $-6.5 \%$ \\
\hline
\end{tabular}

1-minute total rainfall $\times 60$ (Section 3.2), while another is based on the average of rainfall intensity derived from successive rainfall tips over a 1-minute interval. A calibration test was conducted using the SL3-1 raingauge (the best performer in rainfall intensity measurements as mentioned in Section 3.2) to identify which of these two methods would be more appropriate. The test range was from around $6 \mathrm{~mm} / \mathrm{hr}$ to $400 \mathrm{~mm} / \mathrm{hr}$. The results (Table 7) showed that the former method performed better.

\subsection{Rainfall Intensity Recorded during Intense Rainstorms in 2014}

The raingauges at KP recorded rainfall intensity associated with two intense rainstorms that occurred on two separate occasions in 2014. The opportunity is taken to compare the rainfall intensity values calculated by the two different methods as mentioned in Section 3.3 above and the intensity recorded by the two OTT reference gauges.

The 1st rainstorm occurred on the night of March 30, 2014 and hails were reported during the event. Figs. 6 and 7 show the time series of rainfall intensities as recorded by the raingauges at KP calculated based on 1-minute total rainfall x 60 in Fig. 6 and successive rainfall tips in Fig. 7 respectively. (The rainfall intensity of the $0.5-\mathrm{mm}$ Casella raingauge is not plotted as its resolution is too coarse). Peak intensities and times of occurrence recorded by the raingauges are summarized in Table 8.
The peak intensities recorded by the gauges were generally comparable. The rainfall intensity calculated based on 1-minute total rainfall x 60 agreed well with the intensity measured by the two reference OTT gauges while that based on successive rainfall tips was relatively higher. Furthermore, times of peak intensity registered by the SL3-1, Logotronic and OTT raingauges were mostly at 20:32 HKT for the 1 st peak and 21:34-21:35 HKT for the 2nd peak. The OTT raingauges showed no noticeable time delay in detecting the peak intensity although weighing gauges were usually subject to some delay in response due to the time required for the raingauge's microprocessor in deriving the rainfall intensity [6].

The 2nd rainstorm occurred on the night of May 8, 2014. Time series of rainfall intensities calculated based on 1-minute total rainfall x 60 and 1-minute average of rainfall intensity derived from successive rainfall tips are shown in Figs. 8 and 9 respectively. Peak intensities and times of occurrence recorded by the raingauges are summarized in Table 9.

Similar to the feature observed in the 1st rainstorm, rainfall intensity calculated based on 1-minute total rainfall x 60 compared well with the intensity of the two OTT gauges. That based on successive rainfall tips was on the high side.

\section{Discussion}

Considering the overall nearly 3-year results from the two inter-comparison sites at KP and HKIA and 


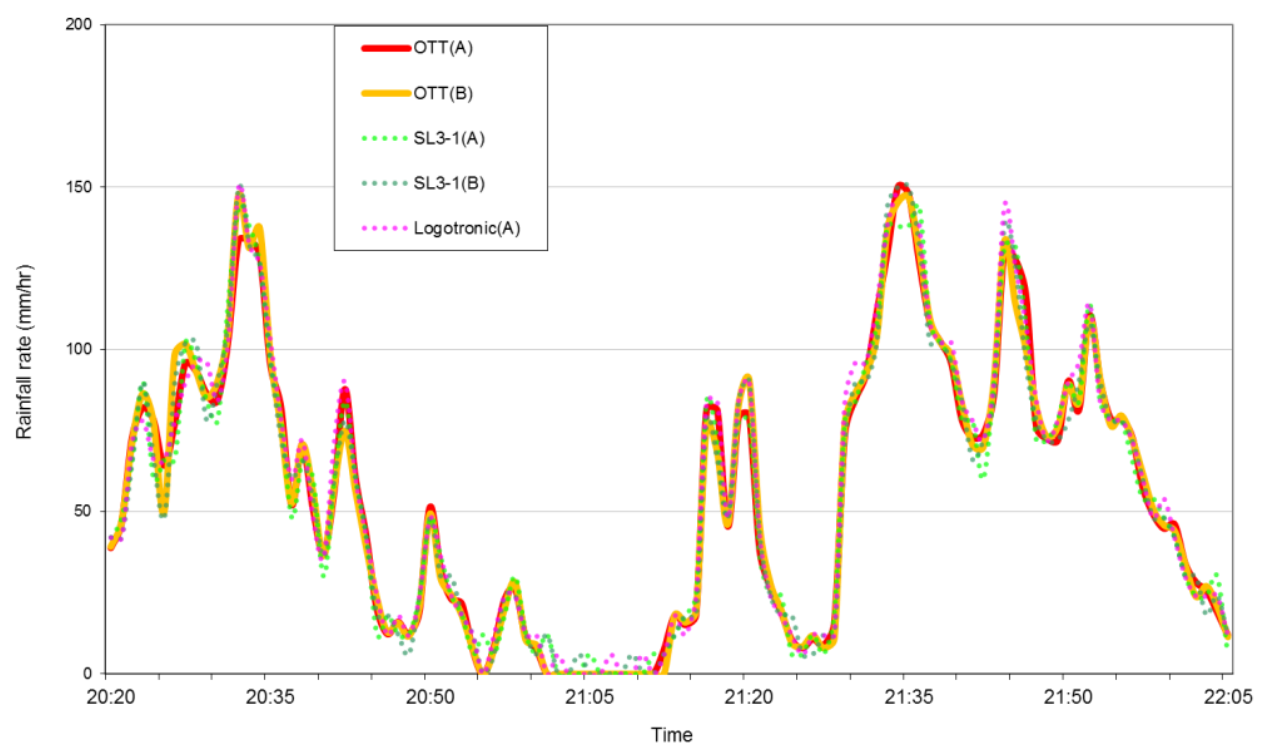

Fig. 6 Time series of rainfall intensities recorded by various $0.1-\mathrm{mm}$ resolution raingauges at the KP site on March $30,2014$. The rainfall intensities were derived from 1-minute total rainfall x 60 (The Logotronic (B) raingauge was not included as it malfunctioned on August 23, 2013).

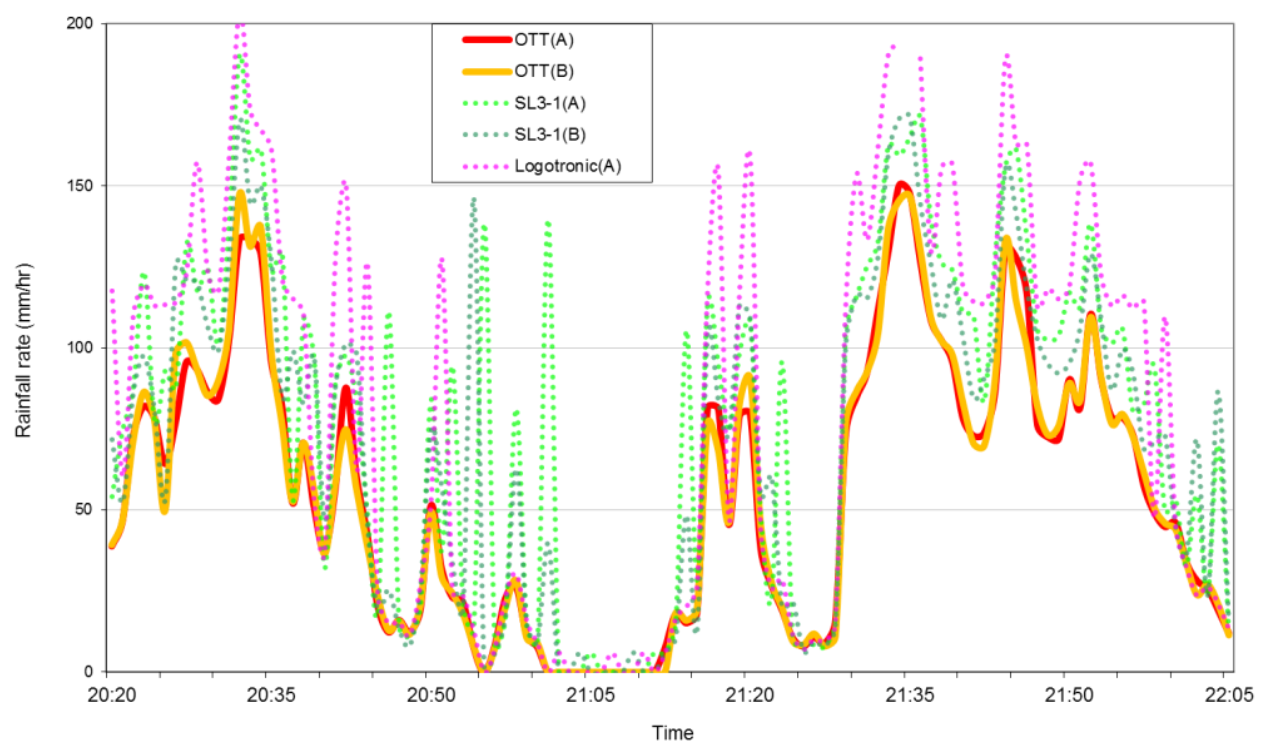

Fig. 7 Time series of rainfall intensities recorded by various 0.1-mm resolution raingauges at the KP site on March 30,2014 . The rainfall intensities were derived from the average of rainfall intensity calculated based on successive rainfall tips over a 1-minute interval.

the operational experience gained in the comparison exercise, the SL3-1 raingauge seems to have better performance in the measurement of 24-hr total rainfall and in terms of robustness in the field environment.

As mentioned in Ref. [2], Logotronic malfunctioned more frequently due to its smaller orifice size and hence suffering from blockage problem due to trapping of leaves or bird's droppings. For the Ogawa raingauge, it was limited by its larger MAPD (> 5\%) for rainfall intensities exceeding 100 $\mathrm{mm} / \mathrm{hr}$ [8]. The performance of ETG was also less satisfactory with comparatively higher MAPD (5.8\%), RMSE $(2.6 \mathrm{~mm})$ and standard deviation of percentage error $( \pm 4.6 \%)$. All Ogawa, Logotronic, ETG and 


\section{Measurements in a Tropical Environment}

Meteoservis raingauges were equipped with electronic devices which were subject to the impact of lightning and prone to failure. Both the Ogawa and Meteoservis raingauges required considerable amount of maintenance works.

The two OTT weighing gauges showed good accuracy when undergoing in-house calibration with uncertainties meeting the WMO's $\pm 5 \%$ and $\pm 2 \%$ requirements for rainfall amount and intensity measurements respectively. Using the two OTT as reference gauges, field results at KP indicated that 5-minute mean rainfall intensity measured by SL3-1 had a RMSE less than or close to $5 \mathrm{~mm} / \mathrm{hr}$ and MAPD smaller than or slightly above $5 \%$, suggesting the

Table 8 Peak rainfall intensities recorded by various $0.1-\mathrm{mm}$ resolution raingauges at the $\mathrm{KP}$ site during the intense rainstorm on the night of March 30, 2014.

\begin{tabular}{|c|c|c|c|c|c|c|c|c|}
\hline \multirow{3}{*}{$\begin{array}{l}\text { Time } \\
\text { hh:mm } \\
\text { RE1 }\end{array}$} & \multicolumn{8}{|c|}{ 1-minute mean rainfall intensity $(\mathrm{mm} / \mathrm{hr})$} \\
\hline & \multirow{2}{*}{ OTT (A) } & \multirow{2}{*}{ OTT (B) } & \multicolumn{2}{|c|}{ SL3-1(A) } & \multicolumn{2}{|c|}{ SL3-1(B) } & \multicolumn{2}{|c|}{ Logotronic (A) } \\
\hline & & & $\mathrm{M} 1^{\mathrm{a}}$ & $\mathrm{M} 2^{\mathrm{b}}$ & $\mathrm{M} 1^{\mathrm{a}}$ & $\mathrm{M} 2^{\mathrm{b}}$ & $\mathrm{M} 1^{\mathrm{a}}$ & $\mathrm{M} 2^{\mathrm{b}}$ \\
\hline $20: 31$ & 102.0 & 105.2 & 114 & 138.4 & 108 & 126.4 & 102 & 158.9 \\
\hline $20: 32$ & 133.5 & 147.4 & 144 & 190.4 & 150 & 170.3 & 150 & 203.9 \\
\hline $20: 33$ & 133.7 & 131.3 & 138 & 158.1 & 132 & 144.5 & 132 & 173.1 \\
\hline $20: 34$ & 129.2 & 137.3 & 126 & 161.2 & 126 & 149.7 & 126 & 167.2 \\
\hline \multicolumn{9}{|l|}{ RE2 } \\
\hline $21: 32$ & 111.4 & 104.3 & 108 & 132.3 & 102 & 127.6 & 114 & 161.4 \\
\hline $21: 33$ & 130.1 & 137.2 & 138 & 162.6 & 144 & 159.9 & 138 & 190.7 \\
\hline $21: 34$ & 150.2 & 145.5 & 138 & 159.2 & 150 & 170.6 & 150 & 193.9 \\
\hline $21: 35$ & 147.7 & 146.9 & 138 & 164.8 & 150 & 171.4 & No d & \\
\hline $21: 36$ & 126.7 & 130.1 & 144 & 171.0 & 132 & 144.5 & 138 & 189.2 \\
\hline $21: 37$ & 108.5 & 109.2 & 108 & 139.4 & 102 & 125.8 & 108 & 130.0 \\
\hline $21: 38$ & 102.2 & 102.1 & 102 & 126.2 & 102 & 108.7 & 102 & 155.8 \\
\hline
\end{tabular}

RE1-Rain Episode 1, RE2-Rain Episode 2, M1-Method 1, M2-Method 2.

a 1 -minute mean rainfall intensity based on 1-minute total rainfall x 60 ;

${ }^{\mathrm{b}} 1$-minute mean rainfall intensity based on the average of rainfall intensity derived from successive rainfall tips over a 1-minute interval.

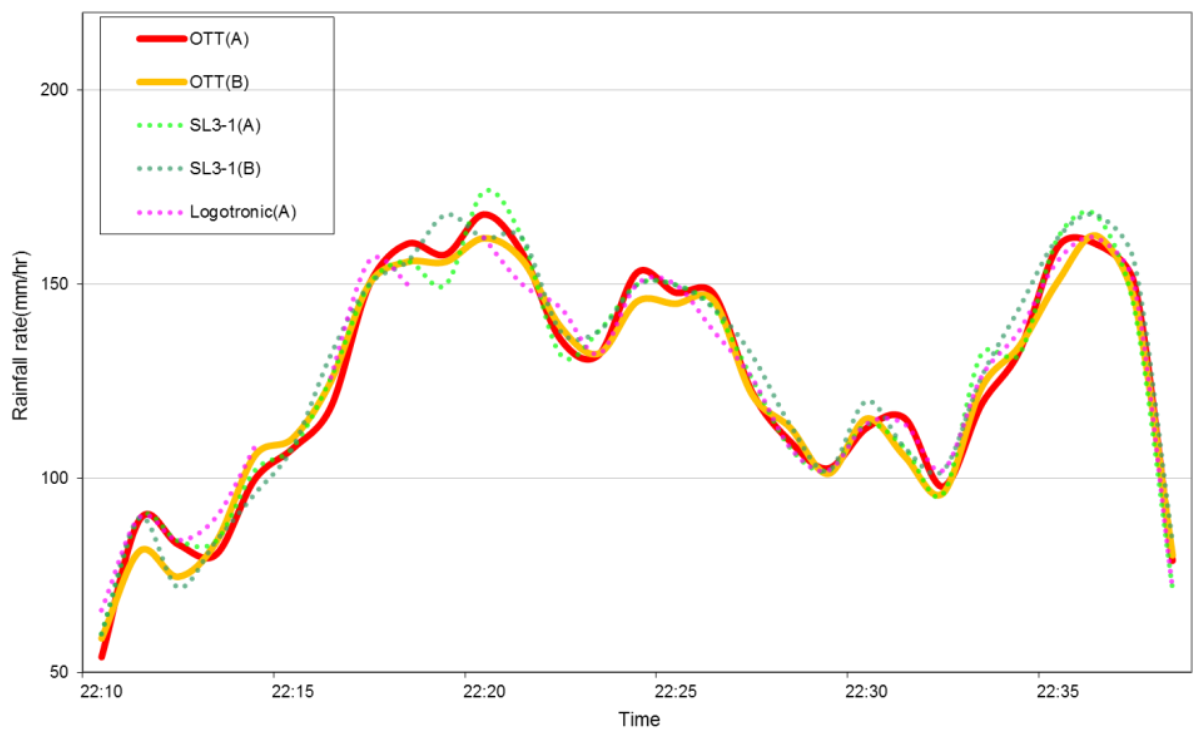

Fig. 8 Time series of rainfall intensities recorded by various $0.1-\mathrm{mm}$ resolution raingauges at the KP site on May $8,2014$. The rainfall intensities were derived from 1-minute total rainfall x 60 (There were a few missing data from the Logotronic (A) raingauge). 


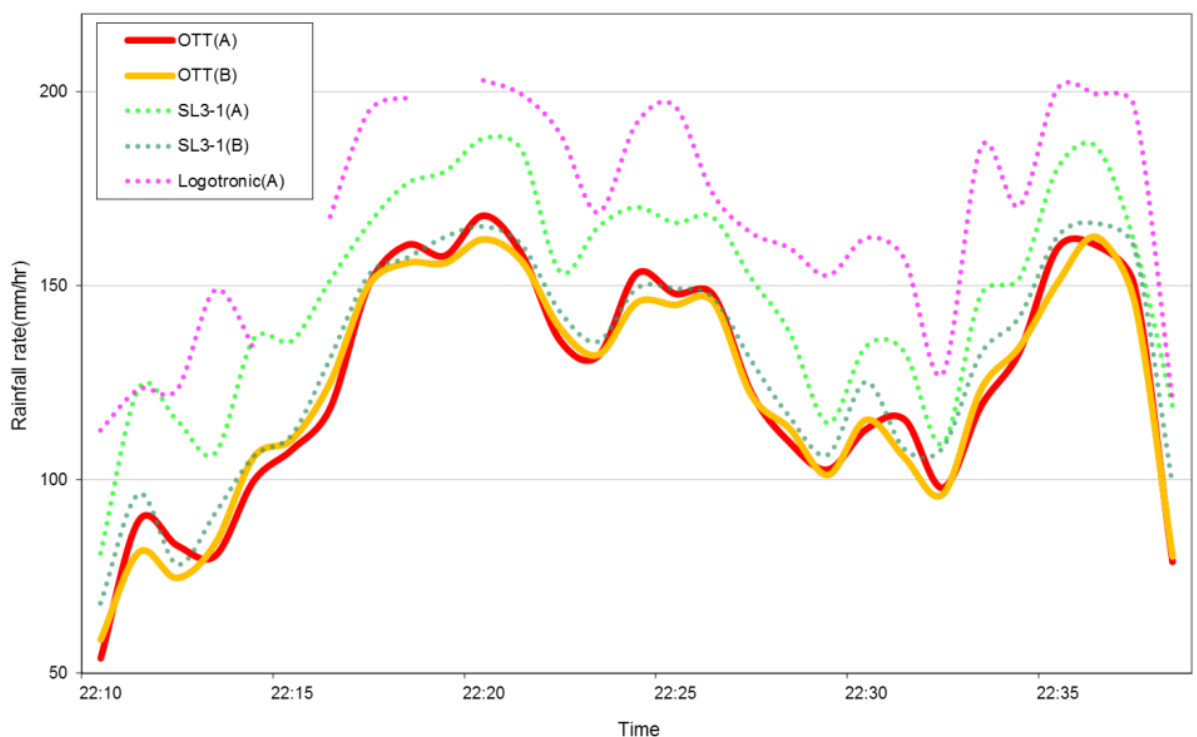

Fig. 9 Time series of rainfall intensities recorded by various $0.1-\mathrm{mm}$ resolution raingauges at the KP site on May $8,2014$. The rainfall intensities were derived from the average of rainfall intensity calculated based on successive rainfall tips over a 1-minute interval.

Table 9 Peak rainfall intensities recorded by various $0.1-\mathrm{mm}$ resolution raingauges at the KP site during the intense rainstorm on the night of May $8,2014$.

\begin{tabular}{|c|c|c|c|c|c|c|c|c|}
\hline $\begin{array}{l}\text { Time } \\
\text { hh:mm }\end{array}$ & & & & lute mea & 1 inten & $\mathrm{nm} / \mathrm{hr})$ & & \\
\hline \multirow{2}{*}{ RE1 } & \multirow{2}{*}{ OTT (A) } & \multirow{2}{*}{ OTT (B) } & \multicolumn{2}{|c|}{ SL3-1(A) } & \multicolumn{2}{|c|}{ SL3-1(B) } & \multicolumn{2}{|c|}{ Logotronic (A) } \\
\hline & & & $M 1^{\mathrm{a}}$ & $\mathrm{M} 2^{\mathrm{b}}$ & $\mathrm{M} 1^{\mathrm{a}}$ & $\mathrm{M} 2^{\mathrm{b}}$ & $\mathrm{M} 1^{\mathrm{a}}$ & $\mathrm{M} 2^{\mathrm{b}}$ \\
\hline $22: 17$ & 150.0 & 150.1 & 150 & 165.8 & 150 & 152.7 & 156 & 194.7 \\
\hline $22: 18$ & 160.5 & 155.8 & 156 & 176.3 & 156 & 157.2 & 150 & 198.3 \\
\hline $22: 19$ & 157.7 & 155.8 & 150 & 179.4 & 168 & 162.6 & No data & \\
\hline $22: 20$ & 168.0 & 161.9 & 174 & 187.9 & 162 & 165.3 & 162 & 202.8 \\
\hline $22: 21$ & 158.1 & 156.3 & 162 & 184.9 & 162 & 160.6 & 150 & 199.2 \\
\hline $22: 22$ & 135.8 & 139.1 & 132 & 153.7 & 138 & 143.4 & 144 & 189.2 \\
\hline \multicolumn{9}{|l|}{ RE2 } \\
\hline $22: 34$ & 132.9 & 134.1 & 132 & 151.8 & 144 & 141.9 & 138 & 170.5 \\
\hline $22: 35$ & 159.7 & 150.8 & 162 & 180.2 & 162 & 162.7 & 156 & 200.7 \\
\hline $22: 36$ & 160.4 & 162.6 & 168 & 185.9 & 168 & 166.1 & 162 & 199.3 \\
\hline $22: 37$ & 150.1 & 146.1 & 144 & 161.4 & 156 & 159.9 & 150 & 196.3 \\
\hline $22: 38$ & 78.8 & 80.2 & 72 & 119.2 & 84 & 98.9 & 72 & 121.2 \\
\hline
\end{tabular}

RE1-Rain Episode 1, RE2-Rain Episode 2, M1-Method 1, M2-Method 2.

a 1 -minute mean rainfall intensity based on 1-minute total rainfall x 60 ;

${ }^{\mathrm{b}} 1$-minute mean rainfall intensity based on the average of rainfall intensity derived from successive rainfall tips over a 1 -minute interval.

possibility of meeting WMO's $5 \mathrm{~mm} / \mathrm{hr}$ and $\pm 5 \%$ requirement.

Regarding derivation of rainfall intensity, both in-house calibration and field measurement results at KP suggested that rainfall intensity calculated based on 1-minute total rainfall x 60 was more appropriate than that based on 1-minute average of rainfall intensity derived from successive rainfall tips.

\section{Conclusions}

Field inter-comparison of automatic raingauges based on five different measurement methods was 
conducted at KP and HKIA in March 2011-December 31,2013 to assess their accuracy in measuring rainfall amount against WMO's $\pm 5 \%$ requirement. During the comparison periods, 142 and 127 rain episodes were recorded at KP and HKIA respectively. SL3-1 outperformed the other raingauges in the comparison in terms of reliability and measurement accuracy. It was also more robust in operation and required less maintenance effort. As such, SL3-1 is potentially the best option in measuring rainfall amount with $0.1-\mathrm{mm}$ resolution in a tropical climate like Hong Kong.

In-house calibration from around $30 \mathrm{~mm} / \mathrm{hr}$ to 400 $\mathrm{mm} / \mathrm{hr}$ showed good accuracy of the two OTT weighing gauges in both rainfall amount and rainfall intensity measurements. Based on field measurements at KP during the two rainstorms on March 30, 2014 and May 8, 2014 respectively, no noticeable time delay was observed for the two OTT raingauges in detecting the peak rainfall intensity.

With OTT serving as reference gauges, 5-minute mean rainfall intensity measured by SL3-1 had lower RMSE (around $5 \mathrm{~mm} / \mathrm{hr}$ or less) and MAPD (less than $5 \%$ ) than those of Logotronic and Casella, and the accuracy was good enough to possibly meet WMO's requirement. In addition to using OTT, SL3-1 may be an alternative choice for measuring rainfall intensity. More rainfall intensity data will be collected for further evaluation in this aspect.

\section{Acknowledgments}

The authors would like to thank their colleagues Mr. Y. H. Wong for helping to conduct the inter-comparison of raingauges at Hong Kong International Airport and preparing the necessary data for analysis. The authors would also like to thank Mr. K. C. Tsui for his invaluable advice and comments.

\section{References}

[1] World Meteorological Organization. 2014. "Guide to Meteorological Instruments and Methods of Observation." WMO-No.8, 2014th ed. World Meteorological Organization, Geneva, Switzerland.

[2] Tam, K. H., Chan, Y. W., Chan, P. W., and Sin, K. C. 2012. "Inter-comparison of Raingauges in a Sub-tropical Environment." Presented at the 2012 WMO Technical Conference on Meteorological and Environmental Instruments and Methods of Observation, Brussels, Belgium

(TECO-2012) http://www.wmo.int/pages/prog/www/IMOP/publications /IOM-109_TECO-2012/Programme_TECO-2012.html.

[3] Yu, C. L., Sin, K. C., and Chan, Y. W. 2013. "Inter-comparison of 0.1-mm Resolution Raingauges in the Measurements of Rainfall Amount and Rainfall Intensity." Presented at the 27th Guangdong-Hong Kong-Macao Seminar on Meteorological Science and Technology, Shaoguan, Guangdong.

[4] Lanza, L. G., and Stagi, L. 2008. "Certified Accuracy of Rainfall Data as a Standard Requirement in Scientific Investigations." Adv. Geosci. 16: 43-8.

[5] Lanza, L. G., Vuerich, E., and Gnecco, I. 2010. "Analysis of Highly Accurate Rain Intensity Measurements from a Field Test Site.” Adv. Geosci. 25: 37-44.

[6] Lanza, L. G., Leroy, M., Alexadropoulos, C., Stagi, L., and Wauben, W. 2006. "WMO Laboratory Inter-comparison of Rainfall Intensity Gauges-Final Report." Instruments and Observing Methods Report No. 84, WMO/TD No. 1304.

[7] Vuerich, E., Monesi, C., Lanza, L. G., Stagi, L., and Lanzinger, E. 2009. "WMO Field Inter-comparison of Rainfall Intensity Gauges, Instruments and Observing Methods (IOM) Report No. 99.” WMO/TD No. 1504. http://www.wmo.int/pages/prog/www/IMOP/publications -IOM-series.html.

[8] Chan, P. W., and Yeung, C. L. 2004. "A Study of Drop-Counting Rain Gauges.” Hong Kong Observatory Technical Note (Local) No. 79. 